УДК 636.596:619:616.61:619:616.98

(C) 2016

Панікар I. І., доктор ветеринарних наук,

Скрипка М. В., доктор ветеринарних наук, Коломак I. О., аспірант

(науковий керівник - доктор ветеринарних наук I. I. Панікар)

Полтавська державна аграрна академія

\title{
ПАТОМОРФОЛОГІЧНІ ЗМІНИ В НИРКАХ ГОЛУБІВ ЗА СПОНТАННОГО КОЛІБАКТЕРІОЗУ
}

\section{Рецензент - доктор ветеринарних наук А. А. Замазій}

\begin{abstract}
У статті наведені результати проведеного моніторингу епізоотичної ситуачії стосовно захворюваності диких голубів в м. Полтава. Вивчено поширеність збудника колібактеріозу, E. Coli серед голубів. На основі проведених патоморфологічних досліджень були виявлені особливості змін у нирках за спонтанного колібактеріозу, що характеризувалися ознаками вогнищевого інтерстиційного гнійного запалення, зернистої дистрофії та утворенням гемосидерину. За хронічного перебігу патоморфологічні зміни супроводжувались утворенням гранульом та розростанням сполучної тканини.
\end{abstract}

Ключові слова: дикі голуби, E. Coli, колігранулематоз, гранульома, нирки, гемосидероз.

Постановка проблеми. Про патогенність кишкової палички та вплив на травну систему ссавців та птиці згадується в повідомленнях багатьох науковців як минулого століття, так і сьогодення [3]. Водночас не завжди враховується той факт, що патогенез даного захворювання являє собою послідовні етапи інфекційно-запального процесу, обумовленого впровадженням патогенного мікроорганізму в різні системи організму, зокрема в сечові шляхи, паренхіму нирки, розвитком локального запалення та синдрому системної запальної реакції, з можливим подальшим розвитком сепсису [4].

Аналіз останніх досліджень і публікацій, у яких започатковано розв'язання проблеми. Вивчення факторів патогенності найбільш поширених збудників гострого інфекційнозапального захворювання нирок, до яких відноситься кишкова паличка, має не тільки науковий, але і практичний інтерес. Патогенні мікроорганізми мають як місцевий вплив на тканини, сприяючи збільшенню ймовірності їх контамінації, викликаючи локальний запальний процес, так i ініціюють системну запальну реакцію. Фактори патогенності надають як прямий, так і непрямий токсичний вплив на макроорганізм, що пов'язано 3 високою біологічною активністю токсинів і їх здатністю викликати функціональні і структурні пошкодження клітини-господаря [5].

Мета роботи полягала у дослідженні мікробної контамінації організму голубів патогенною мікрофлорою.

Завдання: визначити особливості патоморфологічних змін у нирках за колібактеріозу голубів.

Матеріали і методи досліджень. Для вивчення мікробної контамінації організму голубів патогенною мікрофлорою було застосовано бактеріологічні, патоморфологічні та гістохімічні методи досліджень.

Лабораторна діагностика проводилась на базі Регіональної ДЛВМ в Полтавській області. У роботі досліджували трупи птиці, з органів якої було виділено та ідентифіковано збудника Е. Coli., а збудники інших інфекційних хвороб були не патогенними. Патолого-анатомічний розтин проводили методом часткової евісцерації [2]. Для гістологічних досліджень шматочки з різних відділів легень і серця фіксували в $10 \%$ нейтральному розчині формаліну, зневоджували в спиртах зростаючої концентрації та через хлороформ заливали в парафін. Одержані препарати фарбували гематоксиліном Караці та еозином [1].

Результати досліджень. Наші дослідження були спрямовані на моніторинг епізоотичної ситуації щодо інфекційних захворювань диких голубів в м. Полтава. Результатом таких досліджень було встановлено, що серед групи клінічно хворої птиці найбільш часто зустрічається колібактеріоз (хворіс 50\%), сальмонельоз (16,7\%), паразитарні хвороби (33,3\%): капіляріоз та гетеракідоз. Відбір голубів проводився за такими ознаками як: пригнічення, втрата апетиту, розлади травлення. Лабораторна діагностика проводилась на базі Регіональної ДЛВМ в Полтавській області. У роботі досліджували трупи птиці, 3 органів якої було виділено та ідентифіковано збудника E. Coli., а збудники інших інфекційних хвороб були не патогенними. 


\section{ВЕТЕРИНАРНА МЕДИЦИНА}

Під час розтину встановлено дифузне червоне забарвлення нирок у $80 \%$ дослідженої птиці. В інших випадках (20\%) орган набував плямистого забарвлення - ділянки червоного забарвлення чергувались 3 глинистим забарвленням. Гістологічним дослідженням встановлено вогнищеву гіперемію кіркової зони нирок, набряк пухкої волокнистої тканини. Відбувається запальна інфільтрація (лейкоцитами, лімфоцитами та моноцитами) як пухкої волокнистої тканини, так і стінки ниркових канальців. У більшості випадків інфільтрати виявляють навколо кровоносних судин середнього діаметру. Висока щільність розташування клітинних інфільтратів не дає змоги простежити гістологічну будову таких ділянок органу.

В цитоплазмі епітелію звивистих канальців, що розташовуються по периферії вище зазначених осередків, зареєстровано зерна гемосидерину, що мають в одних випадках дифузне розташування, а в інших - у вигляді глибок (конгломератів). Унаслідок нерівномірної концентрації пігменту в цитоплазмі нефроцитів колір таких скупчень варіює від світло-гірчичного до темнокоричневого. Збільшення об'єму нефроцитів відбувається за рахунок збільшення площі цитоплазми та ядра. Ядро розташовується по центру клітини, каріоплазма світліша за норму. У випадках руйнування клітин - зерна гемосидерину розташовуються по всьому периметру канальця. В ділянках інфільтрації та кровонаповнення судин характерним є набряк строми органу. Крім того, утворення гемосидерину відбувається в просвіті кровоносних судин. Слід зауважити, що утворення гемосидерину в судинах наповнених кров'ю не в усіх випадках супроводжується утворенням периваскулярних муфт 3 клітинних інфільтратів та реабсорбцією нефроцитами гемосидерину. На нашу думку, гемосидероз пов'язаний з тим, що в процесі сечоутворення в первинну сечу потрапляє незначна кількість еритроцитів, а можливо вже й продуктів руйнації еритроцитів (ферритину, гемоглобіну).

В подальшому в процесі реабсорбції, що відбувається в проксимальних канальцях, гемоглобіногенні пігменти відкладаються в цитоплазмі нефроцитів, які призводять до утворення зерен гемосидерину. Цей процес носить вогнищевий характер. На великих ділянках органу епітелій звивистих канальців з ознаками зернистої дистрофії. Зустрічаються ділянки характерні для некрозу нефроцитів, при цьому контури апікальної частини паренхіматозних клітин не простежуються, останні збільшуються в об'ємі, набувають вигляду безформенних мас, просвіти канальців набувають щілеподібної форми, контури клітин зливаються зі вмістимим просвітів канальців. Судинні клубочки середнього кровонаповнення, без видимих змін.

В окремих особин (за хронічного перебігу хвороби) зареєстровано чітко окреслені округлі гранульоми, що за розміром у три і більше разів перевищують розмір судинного клубочка (див. рис.), крім того зареєстровано ознаки хронічного інтерстиційного нефриту (заміщення пухкої сполучної тканини кіркової зони на волокнисту).

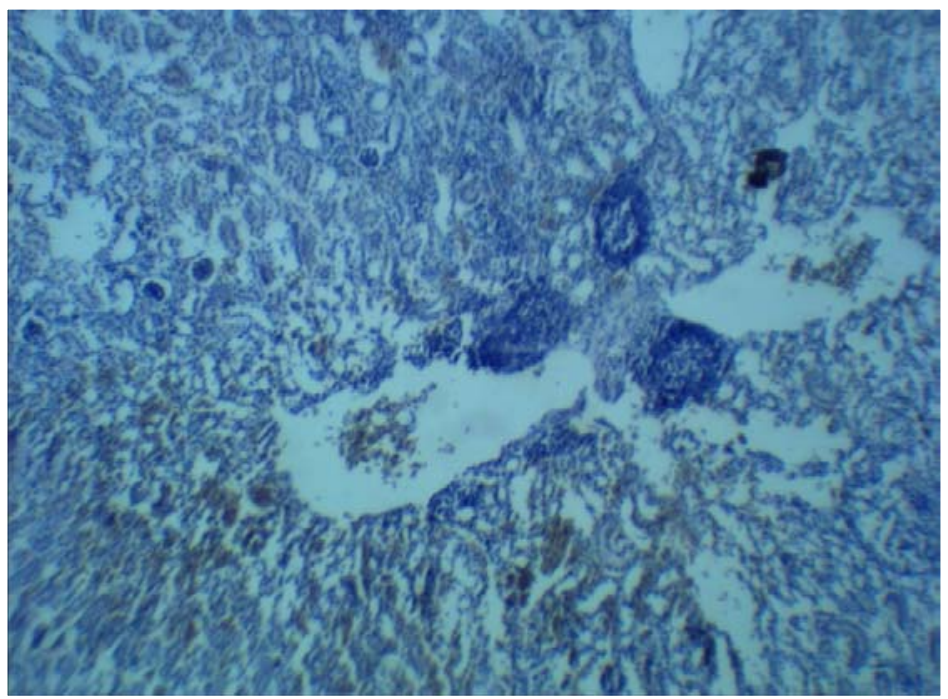

Рис. Гістологічний препарат фрагменту нирки голуба за хронічного колібактеріозу: 1 - ниркові клубочки; 2 - гранульоми; 3 -звивисті канальці нирок; 4 -просвіт кровоносних судин. Фарбування гематоксиліном та еозином. Збільщення $x 200$ 


\section{ВЕТЕРИНАРНА МЕДИЦИНА}

Висновки: 1. Моніторинг епізоотичної ситуації щодо інфекційних захворювань голубів в м. Полтава свідчить, що серед групи клінічно хвоpoї птиці $50 \%$ голубів контаміновані E. Coli., $16,7 \%$ - непатогенними штамами роду Salmonellas pp., збудниками паразитарних хвороб - 33,3 \% (капіляріоз та гетеракідоз).

\section{БІБЛІОГРАФІЯ}

1. Горальський Л. П. Основи гістологічної техніки і морфофункціональні методи досліджень у нормі та при патології : навчальний посібник / Л. П. Горальський, В. Т. Хомич, О. І. Кононський. Житомир : Полісся, 2005. - 288 с.

2. Зон $Г$. А. Патологоанатомічний розтин тварин / Г. А. Зон, М. В. Скрипка, Л. Б. Івановська // ТОВ «Таркус», 2010. - 222 с.

3. Карищева А. Ф. Спеціальна епізоотологія : підручник / А. Ф. Каришева. - Полтава, 2002. $703 \mathrm{c}$.

4. Уродинамика почечной лоханки во время
2. За спонтанного колібактеріозу у диких голубів у нирках встановлено ознаки вогнищевого інтерстиційного гнійного запалення, зернистої дистрофії, гемосидерозу. В окремих випадках патологічний процес супроводжується продуктивним запаленням 3 утворенням гранульом та розростанням волокнистої сполучної тканини.

дистанционной и контактной литотрипсии : 5-я Региональная научно-практическая конференция урологов Сибири [«Актуальные вопросы детской и взрослой урологии»], (Томск, 14-15 сентября 2006) // Сборник научных трудов / [Мудрая И. С., Кирпатовский В. И., Дзеранов Н. К., Казаченко А. В.]. - С. 143-146.

5. Ходырева Л. А. Клинико-лабораторные аспекты диагностики, течения и прогноза мочевой инфекции : автореф. дисс. на соиск. уч. степени д.мед.н. : спец. 14.00.40 «Урология». - М., 2007. $38 \mathrm{c}$. 